\title{
Identification of a serine protease gene expressed by Myxobolus cerebralis during development in rainbow trout Oncorhynchus mykiss
}

\author{
Garry O. Kelley ${ }^{1, *}$, Francisco J. Zagmutt-Vergara ${ }^{1}$, Christian M. Leutenegger ${ }^{2}$, \\ Mark A. Adkison ${ }^{1}$, Dolores V. Baxa ${ }^{1}$, Ronald P. Hedrick ${ }^{1}$ \\ ${ }^{1}$ Department of Medicine and Epidemiology, School of Veterinary Medicine, University of California, Davis, \\ California 95616, USA
}

${ }^{2}$ Department of Medicine and Epidemiology, Lucy Whittier Molecular Core Facility, School of Veterinary Medicine, University of California, Davis, California 95616, USA

\begin{abstract}
Serine proteases have been recognized as key factors in parasite physiology and disease development. We have identified a serine protease gene from Myxobolus cerebralis, MyxSP-1, the myxozoan parasite causing whirling disease in salmonid fishes. The amino acid sequence, as deduced from the cDNA sequence, included a catalytic residue arrangement similar to that of the chymotrypsin family of serine proteases. A real-time TaqMan polymerase chain reaction (PCR) analysis revealed differences in the transcription levels for the chymotrypsin-like protease as found in early, intermediate, and late developmental stages of the parasite in experimentally-infected rainbow trout Oncorhynchus mykiss. MyxSP-1 transcription differed between individual tissues at each sampling point and in the same tissues over time $(\mathrm{p}<0.0001)$. A nonradioactive mRNA in situ hybridization (ISH) protocol was developed to detect MyxSP-1 transcripts. Using a mixture of 3 digoxigenin-labeled antisense mRNA probes, $M y x$ SP-1 transcription was observed in developmental stages of the parasite during the acute and chronic phases of the disease over a $240 \mathrm{~d}$ time period in infected rainbow trout tissues. MyxSP-1 transcription observed by ISH in cartilage and as associated with cartilage destruction was consistent with our real-time TaqMan PCR findings that demonstrated high levels of MyxSP-1 transcription during lesion development. Identifying genes encoding these enzymes and characterization of their functions can lead to the development of new chemotherapeutic protocols and vaccine approaches to control parasitic diseases.
\end{abstract}

KEY WORDS: Salmonid whirling disease $\cdot$ Myxobolus cerebralis $\cdot$ Serine protease $\cdot$ Real-time TaqMan polymerase chain reaction · mRNA in situ hybridization

\section{INTRODUCTION}

Myxobolus cerebralis, a myxozoan fish parasite and the causative agent of salmonid whirling disease, is responsible for severe losses in populations of wild juvenile rainbow trout Oncorhynchus mykiss across North America (Nehring \& Walker 1996, Vincent 1996, Hedrick et al. 1998, Baldwin et al. 2000). M. cerebralis has a complex 2-host life cycle that alternates between a myxosporean and an actinosporean (also referred to as a triactinomyxon) spore stage that are infectious for an aquatic oligochaete Tubifex tubifex and salmonid fishes, respectively (Wolf \& Markiw 1984, Markiw 1989, El-Matbouli et al. 1995, El-Matbouli \& Hoffmann 1998). In the fish hosts, sequential presporogonic stage development occurs in the skin, nerves, and skeletal cartilage. Presporogonic stages that reach skeletal cartilage cause extensive tissue damage (lysis of chondrocytes) and disrupt osteogenesis before undergoing myxospore formation (sporogenesis). Early stages of 
sporogenesis are associated with granulomatous inflammation but myxospores that remain sequestered in areas of bone in the head, gills, and axial skeleton invoke little response from the host (MacConnell \& Vincent 2002). Clinical signs of disease during the acute phase are commonly characterized by darkened skin coloration, skeletal deformities, and periods of radical whirling behavior. Drug treatments that target DNA or RNA synthesis have shown moderate success in controlling the overt signs of disease (El-Matbouli \& Hoffmann 1991, Wagner 2002) but sub-clinical infections often remain, leaving trout as carriers of the pathogen. Eliminating parasite infestations from fishrearing facilities has focused on disrupting the life cycle of the parasite by chemically disinfecting ponds and raceways and using water sources free of fishes or oligochaetes. Managing whirling disease among wild salmonid populations has been more difficult, with major efforts focused on prohibiting stocking with infected farm-reared fishes and reducing conditions that contribute to habitats that may increase the populations of susceptible oligochaetes (Beauchamp et al. 2002, Wagner 2002). Detecting $M$. cerebralis among populations of captive or wild fish stocks is a key step in controlling the spread of whirling disease. Currently, a presumptive diagnosis of whirling disease is dependent on morphological identification of myxospores released by mechanical and chemical treatments from skeletal tissues of infected trout or salmon (Markiw \& Wolf 1974, O'Grodnick 1975). Detection of spores or presporogonic stages in cartilage in hematoxylin and eosin (H\&E)-stained tissue sections have been used as a confirmatory test for $M$. cerebralis (Hedrick et al. 1999a, Baldwin et al. 2000). Recently developed molecular-based tests such as the polymerase chain reaction (PCR), in situ hybridization (ISH), and a newly developed real-time TaqMan PCR test have provided time-saving and more-sensitive alternatives to detect and quantify numbers of the parasite in fish and oligochaete tissues (Andree et al. 1998, Antonio et al. 1998, Baldwin \& Myklebust 2002, Kelley et al. 2004).

Prior research has shown that susceptibility to infection and severity of disease depend on fish species, parasite dose, age and size of the fish at the time of first exposure, and water temperature (Halliday 1976, O'Grodnick 1979, Markiw 1991, 1992, Hedrick et al. 1999a,b, 2001, Vincent 2002). The life cycle of Myxobolus cerebralis and history of whirling disease have been well described, but the pathogenic mechanisms by which the parasite recognizes, invades, migrates, replicates, and induces host cell injury in both the fish and oligochaete hosts are largely speculative. Prior studies (El-Matbouli et al. 1995, MacConnell \& Vincent 2002) have shown that presporogonic stages are involved with rapid penetration of the host epidermis, and eventual lysis and ingestion of chondrocytes. The processes of penetration, migration into and between and lysis of host cells are all processes that are potentially facilitated by proteases of parasite origin. Proteolytic enzymes such as serine protease have been identified as critical factors in lesion formation and virulence of numerous pathogenic organisms (McKerrow 1989, McKerrow et al. 1993). Protease genes are critical elements to normal parasite physiology and development (Rosenthal et al. 1988, McKerrow 1989, 1999, McKerrow et al. 1993, 1999), but also influence parasitic virulence factors and subvert host defenses (Que et al. 2003) and thus are targets for potential chemotherapeutic or anti-parasite treatments. We presume that proteases, including serine proteases, are involved in several key phases of the development of $M$. cerebralis and thereby play a role in causing whirling disease in the fish host. Identifying and characterizing protease gene(s) and their expression during development of $M$. cerebralis have been an aim of our recent studies. In this manuscript we describe the isolation and partial characterization of a serine protease gene (MyxSP-1) expressed by $M$. cerebralis that may underlie one of several pathogenic mechanisms by which the parasite causes disease in the salmonid host.

\section{MATERIALS AND METHODS}

Parasite purification and nucleic acid isolation. A population of known susceptible aquatic oligochaetes was maintained in aquaria for the production of the triactinomyxon stage of Myxobolus cerebralis. The oligochaetes were exposed to myxospores freshly isolated (Markiw \& Wolf 1974) from experimentally infected rainbow trout as previously described (Andree et al. 1998). Beginning at $90 \mathrm{~d}$ post-exposure, triactinomyxons released in the aquarium water were harvested and counted (Markiw 1989, Andree et al. 1998). Purified triactinomyxons were stored at $4^{\circ} \mathrm{C}$ prior to their use for fish exposures or nucleic acid isolation. Genomic DNA (gDNA) was isolated from the triactinomyxon spores using QIAamp ${ }^{\circledR}$ DNA Mini Kit (Qiagen). For RNA purification, $1 \mathrm{ml}$ of RNA Later (Ambion) was added to the purified triactinomyxons to preserve RNA templates. Total RNA was extracted from the purified triactinomyxons using RNeasy ${ }^{\circledR}$ Mini Kit (Qiagen).

Experimental fish and tissue collection. We exposed $7 \mathrm{wk}$ post-hatch rainbow trout $(\mathrm{n}=232)$ to 20000 triactinomyxons per fish in $450 \mathrm{ml}$ of $15^{\circ} \mathrm{C}$ water without aeration for $30 \mathrm{~min}$. An equal number of trout was used as a control group from the same egg lot, and was 
maintained under the same conditions but not exposed to the parasite. Exposed and unexposed fish were maintained in separate $20 \mathrm{l}$ aquaria receiving $15^{\circ} \mathrm{C}$ well water at $21 \mathrm{~min}^{-1}$ and fed once daily with a commercial trout diet. The sample points included: time zero, $5 \mathrm{~min}, 2 \mathrm{~h}, 4 \mathrm{~d}, 10 \mathrm{~d}, 24 \mathrm{~d}, 54 \mathrm{~d}$, and $240 \mathrm{~d}$ postexposure. At each time point, 6 fish were euthanized with $500 \mathrm{mg} \mathrm{l}^{-1}$ ethyl $p$-aminobenzoate (Sigma). Using sterile techniques, approximately 20 to $50 \mathrm{mg}$ of tissue from each of the caudal fin, dorsal fin, gill, muscle, spinal column, and head (near the ventral calvarium) were placed separately into sterile $1.5 \mathrm{ml}$ centrifuge tubes and immediately placed on dry ice and stored at $-80^{\circ} \mathrm{C}$.

Tissue fixation and histological preparation. At each of the sampled time points, 6 fish were preserved in Davidson's fixative for $48 \mathrm{~h}$ and then transferred to $70 \%$ ethanol. After fixation, the fish were processed for standard paraffin embedding, and then sectioned (5-6 $\mu \mathrm{m})$ for mRNA ISH and H\&E staining.

PCR amplification with degenerate serine protease primers. A degenerate primer set (Sakanari et al. 1989) was modified to amplify protease gene fragments from gDNA of the triactinomyxon stage of Myxobolus cerebralis by PCR. The sequence of the degenerate primers are: serine protease forward primer: 5'-TTG GTI GTI ACI GCI GCI CA(C/T) TG3', serine protease reverse primer $5^{\prime}-\mathrm{A}(\mathrm{A} / \mathrm{G}) \mathrm{I}$ GGI CCI CCI $(\mathrm{A} / \mathrm{T})(\mathrm{C} / \mathrm{G})(\mathrm{A} / \mathrm{G}) \mathrm{CT}(\mathrm{T} / \mathrm{G}) \mathrm{CC}-3^{\prime}$. A $50 \mu \mathrm{l} \mathrm{PCR}$ mixture was prepared that contained Advantage ${ }^{\circledR}$-GC 2 PCR reagents (Clontech Laboratories) as follows: $1 \mathrm{X}$ PCR buffer $(40 \mathrm{mM}$ Tricine-KOH, $15 \mathrm{mM}$ KOAc, $3.5 \mathrm{mM} \mathrm{Mg}(\mathrm{OAc})_{2}, 5 \%$ dimethyl sulfoxide, $3.75 \mu \mathrm{g}$ $\mathrm{ml}^{-1}$ bovine serum albumin (BSA), $0.0005 \%$ Nonidet P-40, $0.0005 \%$ Tween-20), 1 M GC-Melt, $200 \mu \mathrm{M}$ deoxynucleoside triphosphates (dNTPs), 1X Advantage-GC 2 polymerase mix $(1.0 \%$ glycerol, $0.3 \mathrm{mM}$ Tris- $\mathrm{HCl}(\mathrm{pH} 8.0), 1.5 \mathrm{mM} \mathrm{KCl}, 1.0 \mu \mathrm{M}$ EDTA), 40 pmol of each primer and $100 \mathrm{ng}$ of gDNA. The mixture was subjected to 35 cycles of amplification $\left(95^{\circ} \mathrm{C}\right.$ for $3 \mathrm{~min}, 94^{\circ} \mathrm{C}$ for $1 \mathrm{~min}, 48^{\circ} \mathrm{C}$ for $1 \mathrm{~min}, 72^{\circ} \mathrm{C}$ for 2 min followed by an extension at $72^{\circ} \mathrm{C}$ for $10 \mathrm{~min})$. After amplification, $10 \mu \mathrm{l}$ of the PCR sample were visualized on a $1.5 \%$ agarose gel. An 810 bp amplicon was excised from the gel and purified using QiAquick $^{\circledR}$ Extraction Kit (Qiagen) and cloned using the TOPO TA Cloning Kit (Invitrogen Corporation). Transformed cells were screened using PCR (protocol described above) and cells containing the desired plasmid were isolated using the QiAprep ${ }^{\circledR}$ Spin Miniprep Kit (Qiagen). Purified plasmid was sequenced using the SP6 and T7 promoter primers with an ABI 377 automated sequencer (Applied Biosystems). Sequences were aligned using the computer program MacDNASIS, version 3.7 (MiraiBio.).
Specific serine protease PCR amplification. Specific primers (see Table 1) designed with the software Amplify (University of Wisconsin Genetics, Madison, WI) were used to amplify MyxSP-1 gene fragments from cDNA templates. Utilizing $300 \mathrm{ng}$ of total RNA, cDNA was synthesized using Omniscript reverse transcriptase (Qiagen) following the manufacturer's protocol. A $50 \mu \mathrm{l}$ reaction mixture containing $1 \mathrm{X}$ PCR buffer (Invitrogen), $1.5 \mathrm{mM} \mathrm{MgCl}$ (Invitrogen), $400 \mu \mathrm{M}$ deoxynucleoside triphosphate, $0.5 \mathrm{U}$ Taq polymerase (Invitrogen), $5 \mu \mathrm{M}$ tetramethyl ammonium chloride, 40 pmol of each primer and $250 \mathrm{ng}$ of cDNA was subjected to 35 cycles of amplification $\left(95^{\circ} \mathrm{C}\right.$ for $3 \mathrm{~min}$, $94^{\circ} \mathrm{C}$ for $1 \mathrm{~min}, 58^{\circ} \mathrm{C}$ for $1 \mathrm{~min}, 72^{\circ} \mathrm{C}$ for $2 \mathrm{~min}$ followed by an extension at $72^{\circ} \mathrm{C}$ for $10 \mathrm{~min}$ ). PCR products were visualized, cloned, and sequenced in the same manner as described above.

5' and 3' rapid amplification of cDNA ends (RACE). The 5' and 3' ends of MyxSP-1 were amplified using a SMART ${ }^{\mathrm{TM}}$ RACE cDNA Amplification Kit (Clontech). First-strand $5^{\prime}$ and $3^{\prime}$ cDNA templates were produced following the manufacturer's protocol. The gene specific primers for RACE amplification were: $5^{\prime} \mathrm{RC}_{\text {Ser }}$ : $5^{\prime}-$ CCT TGG CTA AAT CAA GTC CTG CAC-3'; and 3'RC ${ }_{\text {Ser }}$ : 5'-CTC GTA AGA GCA GAG TCA AGA TCC3'. The RACE PCR reaction $(50 \mu l)$ contained $1 \mathrm{X}$ Advantage 2 PCR buffer $(40 \mathrm{mM}$ Tricine- $\mathrm{KOH}, 15 \mathrm{mM}$ KOAc, $3.5 \mathrm{mM} \mathrm{Mg}(\mathrm{OAc})_{2}, 3.75 \mathrm{\mu g} \mathrm{ml}^{-1} \mathrm{BSA}, 0.005 \%$ Tween-20, $0.005 \%$ Nonidet-P40), $200 \mu \mathrm{M}$ dNTPs, $1 \mathrm{X}$ Advantage 2 polymerase mix (1.0\% glycerol, $0.3 \mathrm{mM}$ Tris- $\mathrm{HCl}$ (pH 8.0), $1.5 \mathrm{mM} \mathrm{KCl}, 1.0 \mu \mathrm{M}$ EDTA), 40 pmol of each primer and $200 \mathrm{ng}$ of $5^{\prime}$ or $3^{\prime}$ cDNA templates. RACE amplification consisted of a denaturation step for $5 \mathrm{~min}$ at $95^{\circ} \mathrm{C}$ followed by 5 cycles of amplification $\left(95^{\circ} \mathrm{C}\right.$ for $3 \mathrm{~min}, 94^{\circ} \mathrm{C}$ for $30 \mathrm{~s}, 75^{\circ} \mathrm{C}$ for $1 \mathrm{~min}, 72^{\circ} \mathrm{C}$ for $2 \mathrm{~min}$ ) and 30 cycles of amplification $\left(94^{\circ} \mathrm{C}\right.$ for $30 \mathrm{~s}$, $68^{\circ} \mathrm{C}$ for $1 \mathrm{~min}, 72^{\circ} \mathrm{C}$ for $2 \mathrm{~min}$ followed by an extension at $72^{\circ} \mathrm{C}$ for $5 \mathrm{~min}$ ). The PCR samples were visualized, purified, cloned, and sequenced as described previously.

Real-time TaqMan PCR systems. Using the $18 \mathrm{~S}$ ribosomal RNA (rRNA) and MyxSP-1 genes of Мyхоbolus cerebralis, and the internal transcribed spacer2 (ITS-2) gene of rainbow trout, 2 primers and an internal fluorescent-labeled probe $\left(5^{\prime}\right.$ end, reporter dye FAM; 3' end, quencher dye TAMRA) were designed using Primer Express software (Applied Biosystems) (Table 1). TaqMan systems for both the 18S rRNA sequence for $M$. cerebralis (GenBank Accession No. AF115253) and the ITS-2 sequence for Oncorhynchus mykiss (AF170543) provided endogenous controls for the parasite and trout tissue, respectively. The length of the PCR products was held very short (between 75 and $120 \mathrm{bp}$ ) to enable high amplification efficiencies. 
Table 1. Myxobolus cerebralis infecting Oncorhynchus mykiss. Sequence for PCR primers and TaqMan probes specific for $O$. mykiss ITS-2 gene, and M. cerebralis 18S rDNA gene and MyxSP-1 protease gene. F: forward primer; R: reverse primer

\begin{tabular}{|c|c|c|c|}
\hline Target & Primers and probes & Sequence $\left(5^{\prime} \rightarrow 3^{\prime}\right)$ & Product length (bp) \\
\hline ITS-2 & $\begin{array}{l}\text { tITS2.2 } \mathrm{F}^{\mathrm{a}} \\
\text { tITS2.157 } \mathrm{R}^{\mathrm{a}} \\
\text { tITS2.75 Probe }\end{array}$ & $\begin{array}{l}\text { TCATCAATCGGAACCTCTGG } \\
\text { AAGGAAGAGCGCACGGG } \\
\text { CACCGAGCCGTCCTGGTCTGAACTTA }\end{array}$ & 120 \\
\hline 18S rRNA & $\begin{array}{l}\text { Myx18-909 } \mathrm{F}^{\mathrm{a}} \\
\text { Myx18-996 } \mathrm{R}^{\mathrm{a}} \\
\text { Myx18-953 Probe }\end{array}$ & $\begin{array}{l}\text { CTTTGACTGAATGTTATTCAGTTACAGCA } \\
\text { GCGGTCTGGGCAAATGC } \\
\text { ACCGGCCAAGGACTAACGAATGCG }\end{array}$ & 88 \\
\hline MyxSP-1 & $\begin{array}{l}\text { SP4812-266 F } \\
\text { SP4812-338 R } \\
\text { SP4812-291 Probe } \\
\text { SP4812-124 F } \\
\text { SP4812-130 R } \\
\text { SP4812-127 } \mathrm{F}^{\mathrm{b}} \\
\text { SP4812-134 R } \\
\text { SP4812-246 F } \\
\text { SP4812-252 } \mathrm{R}^{\mathrm{b}} \\
\text { SP4812-115 F } \\
\text { SP4812-255 R } \\
\text { SP4812-228 F } \\
\text { SP4812-238 R } \\
\text { SP4812-135 F } \\
\text { SP4812-231 R } \\
\text { SP4812-01 F } \\
\text { SP4812-05 R }\end{array}$ & $\begin{array}{l}\text { GCCATTGAATTTGACTTTGGATTA } \\
\text { ACCATTCATGTAAGCCCGAACT } \\
\text { TCGAAGCCTTGACCATCTTTGGCC } \\
\text { GGCGAACGAAGGACCAATCTTTC } \\
\text { GCCTGGAAAACACCGCAGAGATC } \\
\text { CCAAGTTCGGGCTTACATGAATGGTC } \\
\text { CAAAGGATCTTGACTCTGCTCTTAC } \\
\text { GCAAATGGCACTCTTGATTGCATCAG } \\
\text { CATCTACCAAAGTGTTACAGGTGTTGTC } \\
\text { CCTAAGAAGTTCATCAATAGCGAG } \\
\text { TTTTTTTGAGTTGAGGTTGCCG } \\
\text { GAAGTCCTGGCATTTGAGCATATTAC } \\
\text { CCCCTAAACGTTGAATACACGCATTAC } \\
\text { GGCCGAAAGTCGTCAACTGTG } \\
\text { CGTTCTCTTGCAGTTCCCTGTGGC } \\
\text { CCGTACTAGAAAAGGGAGCC } \\
\text { GGTCCGCTCTCATCTTCTC }\end{array}$ & $\begin{array}{r}171 \\
219 \\
189 \\
3889 \\
1735 \\
1386 \\
541\end{array}$ \\
\hline
\end{tabular}

Real-time quantitative PCR sample preparation. Rainbow trout tissues were transferred frozen into 96 deep-well plates containing $800 \mu$ of $1 \times$ ABI lysis buffer (Applied Biosystems) and two $4 \mathrm{~mm}$ diameter grinding beads (SpexCertiprep). Tissue samples were homogenized in a GenoGrinder2000 (SpexCertiprep) for $2 \mathrm{~min}$ at 1500 strokes $\mathrm{min}^{-1}$. After a $30 \mathrm{~min}$ period at $4^{\circ} \mathrm{C}$, total RNA was extracted from the tissue lysates using a 6700 Automated Nucleic Acid Workstation (Applied Biosystems) according to the manufacturer's instructions.

Reverse transcriptase reaction and real-time quantitative TaqMan PCR. CDNA was synthesized using $100 \mathrm{U}$ of SuperScript II (Invitrogen), $300 \mathrm{ng}$ random hexadeoxyribonucleotide $\left(\operatorname{pd}(\mathrm{N})_{6}\right)$ primers, $10 \mathrm{U}$ RNaseOut (Invitrogen), and 1 mM dNTPs in a final volume of $40 \mu \mathrm{l}$. The reverse transcription reaction proceeded for $50 \mathrm{~min}$ at $42^{\circ} \mathrm{C}$. After addition of $10 \mu \mathrm{l}$ of molecular grade water, the reaction was terminated by heating for $5 \mathrm{~min}$ to $95^{\circ} \mathrm{C}$ and immediately cooled on ice.

Each TaqMan PCR reaction contained $400 \mathrm{nM}$ of each primer, $80 \mathrm{nM}$ of the TaqMan probe and commercially available PCR mastermix (TaqMan Universal PCR Mastermix, Applied Biosystems) containing $10 \mathrm{mM}$ Tris- $\mathrm{HCl}$ (pH 8.3), $50 \mathrm{mM} \mathrm{KCl}, 5 \mathrm{mM} \mathrm{MgCl}_{2}$,
2.5 mM dNTPs, 0.625 U AmpliTaq gold DNA polymerase per reaction, $0.25 \mathrm{U}$ AmpErase UNG per reaction and $5 \mu$ l of the diluted cDNA sample in a final volume of $25 \mu$ l. The samples were placed in 96-well plates and amplified in an automated fluorometer (ABI PRISM 7700 Sequence Detection System, Applied Biosystems). Amplification conditions were $50^{\circ} \mathrm{C}$ for $2 \mathrm{~min}, 95^{\circ} \mathrm{C}$ for $10 \mathrm{~min}, 40$ cycles of $95^{\circ} \mathrm{C}$ for $15 \mathrm{~s}$ and $60^{\circ} \mathrm{C}$ for $60 \mathrm{~s}$. Final quantification used a modification of the comparative cycle threshold (CT) method (User Bulletin \#2, Applied Biosystems). The endogenous control for trout tissue (ITS-2) was used to normalize the Myxobolus cerebralis 18S transcription which, in turn, was used to normalize $M y x$ SP-1 gene transcription for each tissue. Subsequently, MyxSP-1 transcription was calibrated against the lowest amount of MyxSP-1 transcription found in each tissue sampled. All normalized MyxSP-1 gene transcription values are reported as the n-fold difference relative to a calibrator cDNA (i.e. lowest target-gene transcription).

In situ hybridization. To prevent RNA degradation, all reagents were prepared (Sambrook et al. 1989) with diethyl pyrocarbonate (DEPC) (Sigma)-treated distilled water, and all equipment was treated with RNase $^{\circledR}$ AWAY (Molecular Bioproducts). Using MyхSP-1 gene-specific primers (Table 1), 3 cDNA 
gene fragments were amplified by PCR and cloned using the methods described above. The 3 cDNA clones were used to make sense and antisense RNA probes using the DIG RNA labeling kit (Roche Applied Science) following the manufacturer's protocol.

The methods used for tissue deparaffinization, permeabilization, and prehybridization are those developed by Antonio et al. (1998), and where appropriate they were optimized for mRNA ISH. Tissue sections were prehybridized at $37^{\circ} \mathrm{C}$ for $2 \mathrm{~h}$ and slides were then rinsed in $2 \mathrm{x}$ saline sodium citrate $\left(\mathrm{SSC}_{i} 1 \times \mathrm{SSC}=\right.$ $0.15 \mathrm{M} \mathrm{NaCl}, 0.015 \mathrm{M}$ sodium citrate, $\mathrm{pH} 7.0$ ), and briefly dried prior to applying the hybridization solution. The sense and antisense hybridization solutions were handled separately, and each solution contained 3 labeled probes for either MyxSP-1 sense or antisense signal detection. The components of the sense and antisense hybridization solutions were similar to the prehybridization solution, except that each probe was added at 1:320 (v:v; $\left.0.003 \mathrm{pg} \mathrm{pl}^{-1}\right)$. Hybridization solutions $(0.75 \mathrm{ml})$ were added to tissue sections and were simultaneously denatured at $100^{\circ} \mathrm{C}$ for $10 \mathrm{~min}$. The tissues were covered with sterile coverslips (RPI) and then incubated overnight at $50^{\circ} \mathrm{C}$ in a humid chamber. Following methods reported by Antonio et al. (1998), stringency washes were performed to remove either unbound probes or nonspecific hybridization of probes.

Detection of hybridization signals. Sense and antisense probe hybridization was detected by an enzymecatalyzed color reaction (Antonio et al. 1998). Tissue sections were incubated with substrate solution for $1.5 \mathrm{~h}$ at room temperature in a humid chamber. Signal intensity was examined microscopically before the reaction was stopped by submersion of slides in distilled water. Tissue morphology was enhanced against the hybridization signals by counter-staining with $0.05 \%$ aqueous Bismarck Brown Y (Sigma) for $30 \mathrm{~s}$. Slides were briefly washed with xylene and permanently mounted with a coverslip using Permount adhesive (Permount). Hybridization signals for MyxSP-1 mRNA transcripts were observed as purple precipitates in tissue sections by light microscopy.

Statistical analysis. All statistical analyses were performed using SPSS 10.0 (SPSS). MyxSP-1 transcription values were log-transformed to enhance normality for posterior statistical analyses. An ANOVA model was used to compare the effects of tissue and time on MyxSP-1 transcription. Differences in MyxSP-1 transcription among sampling times were evaluated for each tissue using univariate ANOVA models followed by pairwise multiple comparisons using Tukey's Honestly Significant Difference (HSD) test to adjust for unequal sample sizes. For all the statistical analyses, $\mathrm{p}<0.05$ was considered significant.

\section{RESULTS}

\section{MyxSP-1 sequence analysis}

Amino acid sequence analysis for $M y x$ SP-1 showed 3 catalytic sequences (His-54, Asp-248, Ser-310) that are characteristic for serine proteases (Hartley 1964). Additional sequence data obtained by $5^{\prime}$ and $3^{\prime}$ RACE amplification allowed a prediction of the open reading frame for MyxSP-1. MyxSP-1 contained a complete coding sequence from the initiation codon ATG (Met1) to the stop codon TGA, and a $5^{\prime}$ and $3^{\prime}$ untranslated region (UTR) (Fig. 1; GenBank Accession No. AY275708). A determination of the initiation codon was based on Kozak's initiation consensus sequence (Kozak 1981, 1999). No introns were found based on alignments of the genomic MyxSP-1 sequence with the MyxSP-1 cDNA sequence (data not shown). The 3 ' UTR of MyxSP-1 contained a 366 bp stretch that complemented portions of the 18S rDNA and ITS-1 genes described for Myxobolus cerebralis (present Fig. 1, and Andree et al. 1999). A BLASTP search (Altschul et al. 1990) revealed no detectable amino acid similarities outside the catalytic sites for MyxSP-1 compared to serine protease genes from other species (data not shown). However, the MyxSP-1 catalytic triad was aligned with catalytic regions from other eukaryotic serine proteases, and the conservation of the catalytic triad was confirmed (Fig. 2). A simple sequence comparison of the predicted mature MyxSP-1 protein revealed limited sequence homology (22 to $28 \%$ ) with the mature serine protease sequences from selected eukaryotic organisms (Fig. 2).

\section{Distribution of MyxSP-1 transcripts across tissues and sampling time}

Differences in the transcription of $M_{y x S P}-1$ were found between individual tissues during the course of this study (Fig. 3). The overall comparison for the effects of tissues on the log-transformed MyxSP-1 transcription over time was highly significant $(\mathrm{p}<0.0001)$. No protease transcription was found for tissues collected from control fish (uninfected). At 5 min post-exposure, mean MyxSP-1 transcription values found in the gill were nearly 10 -fold greater than levels detected in the caudal fin. As expected MyxSP-1 transcription was not detected in the spine and head tissues at $5 \mathrm{~min}$ post exposure. MyxSP-1 transcription peaked at $2 \mathrm{~h}$ post exposure in the gill and dorsal fin epithelial tissues. The first indication of protease transcription was observed in the spine and head tissues at $2 \mathrm{~h}$ post exposure. Mean MyxSP-1 values observed in spinal tissues at $4 \mathrm{~d}$ post exposure increased nearly 10 -fold from lev- 


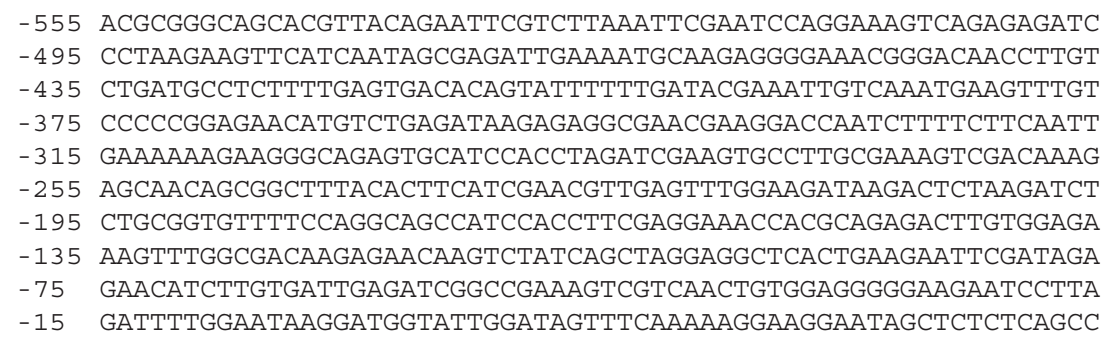
$\begin{array}{llllllllllllllll}M & V & L & D & S & F & K & K & E & G & I & A & L & S & A & 15\end{array}$

46 AGAAAACGGTTGAGGAGACATGTTAGAGCAGACAATGCCAGGTGTGTCTGGAGACGAGCC $\begin{array}{lllllllllllllllllllllllllll}R & \mathrm{~K} & \mathrm{R} & \mathrm{L} & \mathrm{R} & \mathrm{R} & \mathrm{H} & \mathrm{V} & \mathrm{R} & \mathrm{A} & \mathrm{D} & \mathrm{N} & \mathrm{A} & \mathrm{R} & \mathrm{C} & \mathrm{V} & \mathrm{W} & \mathrm{R} & \mathrm{R} & \mathrm{A} & 35\end{array}$

106 AAAGAAACGAGTTGCACCAGATATACCATCAGGGCCAGTCGAAGTTGTTGGGCTCATTGC $\begin{array}{llllllllllllllllllllll}K & E & T & S & C & T & R & Y & T & I & R & A & S & R & S & C & \text { W } & A & H & \text { H } & C & 55\end{array}$ 166 ATTGACTTTATTAAATACATCCGTACTAGAAAAGGGAGCCATAAGATCAGGAAATTTGTC $\begin{array}{lllllllllllllllllllll}I & D & F & I & K & Y & I & R & T & R & K & G & S & H & K & I & R & K & F & V & 75\end{array}$ 226 AGAGAAACAGATTCAAGAAGACTGAAGAGACATAAGTTGAATCTCAGAGGGCACATTCCA $\begin{array}{lllllllllllllllllllll}R & E & T & D & S & R & R & L & K & R & H & K & L & N & \text { L } & R & G & H & I & P & 95\end{array}$ 286 GAGAGAATTATAGTCGACGAGCAATCTCCTCGGACGAGCATGTACACTTTGTATTGTTCC $\begin{array}{lllllllllllllllllllll}\mathrm{E} & \mathrm{R} & \mathrm{I} & \mathrm{I} & \mathrm{V} & \mathrm{D} & \mathrm{E} & \mathrm{Q} & \mathrm{S} & \mathrm{P} & \mathrm{R} & \mathrm{T} & \mathrm{S} & \mathrm{M} & \mathrm{Y} & \mathrm{T} & \mathrm{L} & \mathrm{Y} & \mathrm{C} & \mathrm{S} & 115\end{array}$ 346 GATTTTTGGGTTATGAGTTCAAAAGCCCGTGCAGGACTTGATTTAGCCAAGGAAATTGAG $\begin{array}{lllllllllllllllllllll}D & F & \text { W } & \text { V } & \text { M } & \text { S } & S & K & A & R & A & G & \text { L } & \text { D } & \text { L } & \text { A } & \text { K } & \text { E } & \text { I } & \text { E } & 135\end{array}$ 406 TATGATTGGGCCATTGAATTTGACTTTGGATTATTCGAAGCCTTGACCATCTTTTGGCCA $\begin{array}{lllllllllllllllllllll}Y & D & W & A & I & E & F & D & F & G & L & F & E & A & L & T & I & F & \text { W } & \text { P } & 155\end{array}$ 466 AGTTCGGGCTTACATGAATGGTCGTACGACAGGAAAGGCCGAGTCTTTGAGAGCTCTTTT $\begin{array}{lllllllllllllllllllll}S & S & G & L & H & E & W & S & Y & D & R & K & G & R & V & F & E & S & S & F & 175\end{array}$ 526 TTCGCTGAACGCTTCCTAGCCTTACGTTTGTGGAATGAGAGGACTGGATTGGACCTTGAG $\begin{array}{lllllllllllllllllllll}F & A & E & R & F & L & A & L & R & L & \text { W } & N & E & R & T & G & L & D & L & E & 195\end{array}$ 586 ACTGACAGGAGCGACTCTACTGCCAAAACCGACGTTTCCCAGCTACCAAAAGTTCTTTCG $\begin{array}{lllllllllllllllllllll}T & D & R & S & D & S & T & A & K & T & D & V & S & Q & L & P & K & V & L & S & 215\end{array}$ 646 AGAAACCTCGTAAGAGCAGAGTCAAGATCCTTTGAGTCGATGGTTGATAGAGAAGCCAGA $\begin{array}{lllllllllllllllllllll}R & N & L & V & R & A & E & S & R & S & F & E & S & M & V & D & R & E & A & R & 235\end{array}$

706 GAGAAGATGAGAGCGGACCTTGAGGCTGACGAACTTGACACTGCGCTTTTCTGGCATTTA $\begin{array}{lllllllllllllllllllll}E & \text { K } & \text { M } & \text { R } & \text { A } & \text { D } & \text { L } & \text { E } & \text { A } & \text { D } & \text { E } & \text { L } & \text { D・ } & \text { T } & \text { A } & \text { L } & \text { F } & \text { W } & \text { H } & \text { L } & 255\end{array}$

766 AGTGGAATATTAGAAGGGAAAAATGGATCGGAGACTGTGATCAACGGGCCCCTGAGAGGG $\begin{array}{lllllllllllllllllllll}S & G & I & L & E & G & K & N & G & S & E & T & V & I & N & G & P & L & R & G & 275\end{array}$ 826 GACCTGAGAATTCCATATGTGTTTTGGAGTTTGATAGATTCGCAGCTATTAGACCGACGA $\begin{array}{llllllllllllllllllllll}D & L & R & I & P & Y & V & F & \text { W } & \text { S } & \text { L } & \text { I } & D & \text { S } & Q & \text { L } & \text { L } & \text { D } & R & R & 295\end{array}$ 886 TTAGAAGATGAAACTTCTTTTACTCTGGGTGCGATAATCTCAAGTGGCAGTGACGAGCGT $\begin{array}{lllllllllllllllllllll}L & E & D & E & T & S & F & T & \text { L } & \text { G } & \text { A } & \text { I } & \text { I } & \text { S } & \text { S• } & \text { G } & \text { S } & \text { D } & \text { E } & \text { R } & 315\end{array}$ 946 GAAAGGGCTCCAGAACTTGAAACCGACTCGTCCGATGATTCATTATCCAGAGGAAGTGGA $\begin{array}{lllllllllllllllllllll}E & R & A & P & E & L & E & T & D & S & S & D & D & S & L & S & R & G & S & G & 335\end{array}$ 1006 ACGACACGCGACAGCGCTTGGATTTTTTCTGGAGTAGAGACTATAATTGGACGTGAATTA $\begin{array}{lllllllllllllllllllll}T & T & R & D & S & A & W & I & F & S & G & V & E & T & I & I & G & R & E & L & 355\end{array}$ 1066 TTGATTTCCTTGGAGATATCCTTAGAGACCGGCACGAGAAAAGGAGAGGGAGAAGGGACC $\begin{array}{lllllllllllllllllllll}L & I & S & L & E & I & S & L & E & T & G & T & R & K & G & E & G & E & G & T & 375\end{array}$ 1126 TTGCTAGACTTTTCTTTCTTCACAGACTTGGTCTGAGATTGGCAGGACTGGAAGTGTATT $\begin{array}{lllllllllllllllll}L & L & D & F & S & F & F & T & D & L & V & *\end{array}$ 1186 GAGAAATCTTTCAGGTTGTTAGATTTGAAGTCCTGGCATTTTGAGCATATTACAAGCACT 1246 TTACACTTTATGAACATTAATGAAATGGTCTCTTGCAAGTATCGAGTTGAGTTAAATGAG 1306 AGCCACAGGGAACTGCAAGAGAACGAGGCCCTGTGGAATTGGAATAAAAGTAGAGGAAAT 1366 TTGATTATCCATTACTATAGGAAGAAAAGCCGCCAAAGCCGAGTAAACCACATCAACATG 1426 ATTGACTTCGGACTGCTTCGTCGGGGCATTAAGGTTTTCAGGCTGAGTAGGATTCACGGG 1486 TTGAGATGGGGGCATGATTTGAATTTTCCCAAGAAAATTGACTTTTTTTCCCCGATGACT 1546 TACGAAATTGAGATTCGGTCAGAGGGGACCTTTGATTTATTTCTGTCACGGGACGGTAAA 1606 ATTTTTTGGTCTGCCGGGCTGGGGAGAGAAAAACATCTGAGACGTTTTTTGGAAAATTAT 1666 TTGTGGCGGCAGGCTTTGAGCCTAGAAAGCCCTAAGTCAGGATTAACAACAGGCACATGC

Fig. 1 (above and facing page.) Nucleotide and deduced protein sequence of MyxSP-1. Numbers on left denote nucleotide sequence, those on right amino acid sequence. Amino acid sequence starts with the methionine (Met-1) residue and is represented by the single-letter code below the nucleotide sequence. Residues in boldface correspond to relatively conserved catalytic motifs for serine proteases. Catalytic active site residues His-54, Asp-248, and Ser-310 are in bold and designated by dots (•). Underlined sequence significantly complements a conserved portion of the 18S rRNA and ITS-2 gene of Myxobolus cerebralis. 


\begin{abstract}
1726 CGGTTGAACACATGGTGTTCAAGGCTGAGTCTGGGTTATTTACTGAGGACGAGTAGTGAA
1786 CGCTGGAAGCACGAGAATCTTGTAGGGAAATTGTTTCGGGATAGCTCGGCAACTTTTCCA

1846 ACGATAGAACATAGCGAACTTTGGGCAGAACCCAACACAATACTAAGATTGGCCACTCCC

1906 TTGAAGCAAGGCGGAGATATCCGCTTGACGCAAGTTGTTAAATTTGAGGCCATTGTTGAG

1966 AGAGAATTGAGGAGCCGTGAGGCGGTGAGTTTTGGCTCATATTTTGCGCGCCTGACGGGG

2026 GTCGAATTATTGGAAGAGGGTAAGGCGGTAGGCGTAGATGCGCCACGGGAATTATCAAAC

2086 ATCTTGTTGTTTGACTTTTTTCGCGCCATAATATGTATGCGGTTTAGGTCGATTTATCTA

2146 AGTATACTTATCAAAAAAAATTCTGGGAATTCCGGTTTTTTTTCAGGAGTAAAATTAAAC

2206 GCACTGACCACTAGAAATTGTGATGCCCTAAGATGTCCTGGGCTGCACGCGCGCTACAAT

2266 GATGGTGACAGCGAGTTTCTAGGTCGAGAGACCTGGCAATCTTGTAATCATCATCGTGAT

2326 GGGATTGACCATTGTAATTTGGTCATGAATAGGAATTCCTGTAGGCGCACTTTATTAGAG

2386 TGTGCCGAACGAGTCCCTGCCCTTTGTACACACCGCCCGTCACTACTACCGAGTGAATCG

2446 TGTCATGATGCCTTGGGACCGGACGTATTTGGAGCTGCAAGGCTTGAAATACGCTGGGAT

2506 CGATGTAAAATGGTGCAATTTCGAGGAAGTAAAAGTCGTAACAAGGTTTCCGTAGGTGAA

2566 CCTGCGGAAGGATCATTGACGTTTACACAAACATTTTGTACGTTGTACGTATTATTCGAG

2626 AAATTACATCTGTTGCTGAAGCTGTGTCTCAGACTAGTTGAGGAGAGTCGCATTACGAGA

2686 AAGCATTCTTCTAGTCGCTTCAGCAACACAGAGAAATCAAGACGACCTCCACTTTTAAAT

2746 ATAATCACTGAGAGTAGACTACTTATTTCGTCTATTCTGTTCGACATTGATGAGACAATA

2806 GTGAACTTTAGAGTAATATTAGTCTTTGTTTGGGAATTTTTAATCGTGTTGTATAAAGCG

2866 GTTGTGTTTATAAATGTGAATGATAAGTATTTCCTGTTCGTTGGGTATGTGTGTAATGCG

2926 TGTATTCAACGTTTAGGGGTGCTCTATTTTCACAGAGTGAGATTTTACGAGTTGATATAT

2986 TCAATAACCATTAACGGTGGATCACTTGGCTCGAGGACGATGAAGAACGTGGCAAATGCG

3046 ATAAGTGATGCGATTCGCAAGCCTAGTGAGTCATCAAGTTTGAACGCAAATGGCACTCTT

3106 GATTGCATCAGGAGTATGTCTGGTTGGGGTTGTTTTTTGAGATACGTCACACGGTTGGCT

3166 TTGCAATTGATGTGCGAATATACACTAGTTGTATATAGAGTTGGGTGTGAAACCGAAGCG

3226 CGGGTTCTCATCTCAAATGGATTGGACAACACCTGTAACACTTTGGTAGATGTATTAATT

3286 GTTGAATTTGTTGGTGAAAACTTTAGAGTACAACAATGTGTTGCACCTATTAAAAGATAC

3346 AGTAAGTTTATAATTATAAATTTACGGCAACCTCAACTCA 25
\end{abstract}

Fig. 1 (continued)

els detected earlier at $2 \mathrm{~h}$ post exposure. The MyxSP-1 transcription found in the nerve tissues of the spine at $4 \mathrm{~d}$ was 12-fold greater than that of the caudal fin and head tissues. At $10 \mathrm{~d}$, mean levels of $M y x S P-1$ transcription followed a general decreasing trend in the gill and dorsal fin tissues, albeit transcription remained greater than those levels detected in the remaining tissues. Mean MyxSP-1 transcription measurements in spine tissues at $10 \mathrm{~d}$ post exposure decreased 8-fold from prior transcription levels observed at $4 \mathrm{~d}$ post exposure. There was at least a 15-fold increase in MyxSP1 transcription found at $24 \mathrm{~d}$ in the spine compared to protease transcription detected in the caudal fin. At $54 \mathrm{~d}$ post exposure, relatively high levels of protease transcription remained in the spine but the overall protease transcription in all tissues sampled exhibited a decreasing trend. At $240 \mathrm{~d}$, protease transcription was observed in the spine and head but in no other tissues.

MyxSP-1 transcription changed significantly ( $p<$ 0.0001 ) over the sampling period for all tissues except for muscle ( $p=0.179$; Fig. 3). MyxSP-1 transcription at $2 \mathrm{~h}$ in the caudal fin was significantly greater than that for all other time points. MyxSP-1 transcription measured at $2 \mathrm{~h}$ in the dorsal fin was significantly greater

\footnotetext{
Myxozoan (Myxobolus cerebralis)

Cnidarian (Aurelia aurita) - Type s1A serine protease

Nematode (Trichinella spiralis) - stage-specific serine protease

Trematode (Schistosoma mansoni) - elastase 2a

Insect (Anopheles gambiae) - trypsin-like protease

Crustacean (Panulirus argus) - trypsin-like protease

Frog (Xenopus laevis) - epidermis-specific serine protease

Mouse (Mus musculus) - Elastase 1

Rat (Rattus norvegicus) - chymotrypsin-like

Human (Homo sapiens) - plasminogen
}

$\begin{array}{lll}\text { RSCWAHCID } & \text { DELDTALFWH } & \text { LGAIISSGSD } \\ \text { ILTASHVCV } & \text { LTNDIALIKL } & \text { ITAPGDSGGP } \\ \text { VVTAAHCVQ } & \text { LHNDIAVLEL } & \text { DSCNGDSGG } \\ \text { VLTAGHCVC } & \text { SGFDIALTML } & \text { ITAPGDSGGP } \\ \text { ILTAAHCID } & \text { NNYDIALELE } & \text { GTCRNDSGGP } \\ \text { VLTAAHCVD } & \text { VDNDMALLRL } & \text { DSCQGDSGGP } \\ \text { VMTAAHCID } & \text { SSGDIALIEL } & \text { DACQGDSGGP } \\ \text { VMTAAHCVD } & \text { AGYDIALLRL } & \text { SGCQGDSGGP } \\ \text { VVTAAHCKV } & \text { MNNDLTLLKL } & \text { SSCQGDSGGP } \\ \text { VLTAAHCLE } & \text { TRKDIALLKL } & \text { DSCQGDSGGP }\end{array}$

Fig. 2. Conserved residues of catalytic triad for serine proteases (boldface) and regions flanking the active sites for comparison. Amino acid sequences surrounding the catalytic active site of MyxSP-1 from Myxobolus cerebralis were aligned to serine proteases from a cnidarian (Aurelia aurita; AAO12214), nematode (Trichinella spiralis; AAD09211), trematode (Schistosoma mansoni; AAM43941), insect (Anopheles gambiae; S40003), crustacean (Panulirus argus; AAK48894), frog (Xenopus laevis, BAA84941), mouse (Mus musculus; BAB25008), rat (Rattus norvegicus; NP_446461), and human (Homo sapiens; NP_000292). Amino acids are in single-letter code 


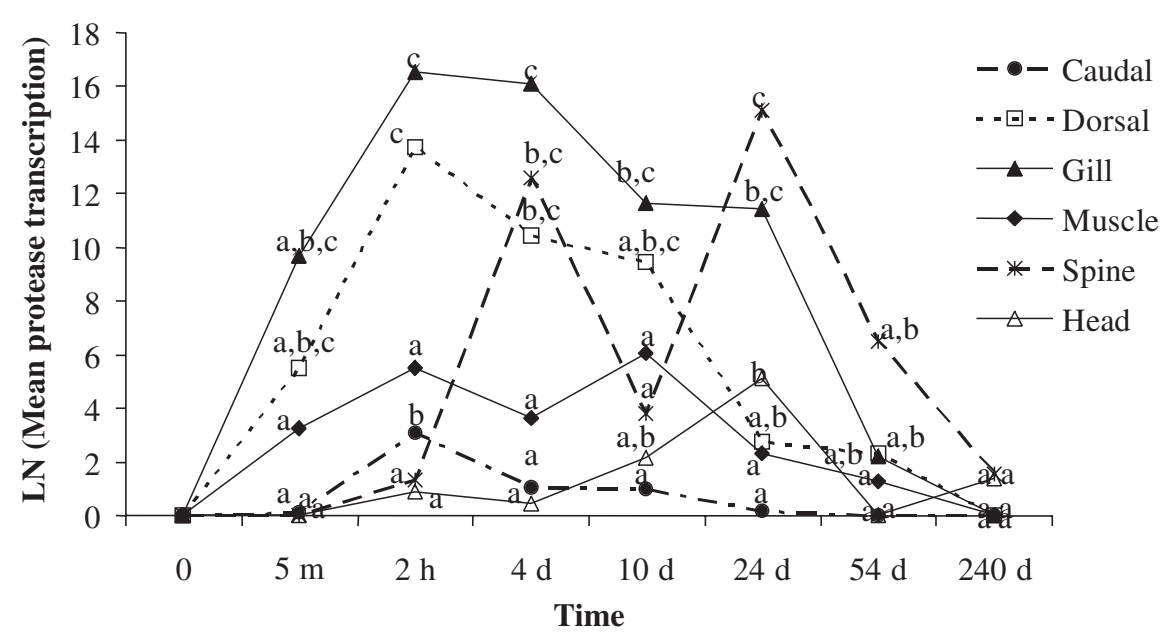

Fig. 3. Myxobolus cerebralis infecting Oncorhynchus mykiss. Transcription levels for MyxSP-1 during M. cerebralis development in rainbow trout tissues over $240 \mathrm{~d}$ time course measured by real-time TaqMan PCR. Results represent natural log (LN) mean of normalized linear amounts of $M y x$ SP-1 transcription relative to the weakest protease signal (also referred to as the calibrator) in each tissue. Differences in MyxSP-1 transcription among sampling times for each tissue are represented by superscripts $\mathrm{a}, \mathrm{b}, \mathrm{c}$, whereby mean protease transcription for each tissue with same superscript(s) was not significant different at $95 \%$ confidence level

than transcription detected at 24,54, and $240 \mathrm{~d}$ post exposure. MyxSP-1 transcription in gill tissues at $2 \mathrm{~h}$ and $4 \mathrm{~d}$ differed significantly from levels measured at 54 and $240 \mathrm{~d}$ post exposure. At $24 \mathrm{~d}$, MyxSP-1 levels measured from head tissues were significantly greater than those at earlier or later time points. Also, MyxSP1 levels measured at $24 \mathrm{~d}$ from the spine were significantly greater than transcription levels for all other time points but $4 \mathrm{~d}$.

\section{Location of MyxSP-1 transcription in rainbow trout}

Using the mRNA ISH test, MyxSP-1 transcription was observed associated with all developmental stages seen in the tissues of infected fish over a $240 \mathrm{~d}$ time period. A combination of 3 antisense probes yielded positive signals associated with sporoplasm aggregates infecting host epithelium at $5 \mathrm{~min}$ and $2 \mathrm{~h}$ post exposure (Fig. 4B). MyxSP-1 antisense probes bound to developmental stages were found throughout the peripheral and central nervous system (CNS) tissues at $4 \mathrm{~d}$ (Fig. 4D) and $10 \mathrm{~d}$ (Fig. 4F) post exposure. Parasite stages at these time points were elongated, spindleshaped, and associated with no host-tissue reaction. Also at $10 \mathrm{~d}$ post exposure, MyxSP-1 antisense signals were associated with presporogonic stages amassed in close proximity to chondrocytes in the cartilage of the head (Fig. 4F) and spine. There was no host-cell response to parasites in this location at this time point, as observed by histopathology. However, by $24 \mathrm{~d}$ post exposure, MyxSP-1 antisense signals were commonly associated with presporogonic stages in distinct areas of host-tissue degeneration characterized by stages infiltrating and lysing cartilage of the head (Fig. 5B). Positive MyxSP-1 transcription detected at 54 and $240 \mathrm{~d}$ post exposure was from presporogonic stages frequently associated with severe cartilage damage characterized by lysis and degeneration of chondrocytes in the head (Fig. 5D,F). No positive signals were observed using the control MyxSP-1 sense hybridization solution with infected fish tissues (Fig. 5G). In addition, no positive signals were observed in tissues from control uninfected fish with either the sense or antisense $\mathrm{Myx}_{\mathrm{SP}}-1$ hybridization solutions (data not shown).

\section{DISCUSSION}

The identification and initial characterization of a serine protease gene for Myxobolus cerebralis is the first we are aware from a member of the phylum Myxozoa. Previous reports have shown other myxozoan fish parasites are capable of producing proteolytic enzymes responsible for tissue deterioration and possibly parasite encystation (Bilinski et al. 1984, Martone et al. 1999). However, these prior studies did not report nucleotide or protein sequence data along with the described protease activity. Under the conditions and time points tested, our real-time TaqMan PCR analysis provided a relative assessment for MyxSP-1 mRNA transcription. Furthermore, our mRNA ISH test demonstrated the ability to visually detect MyxSP-1 

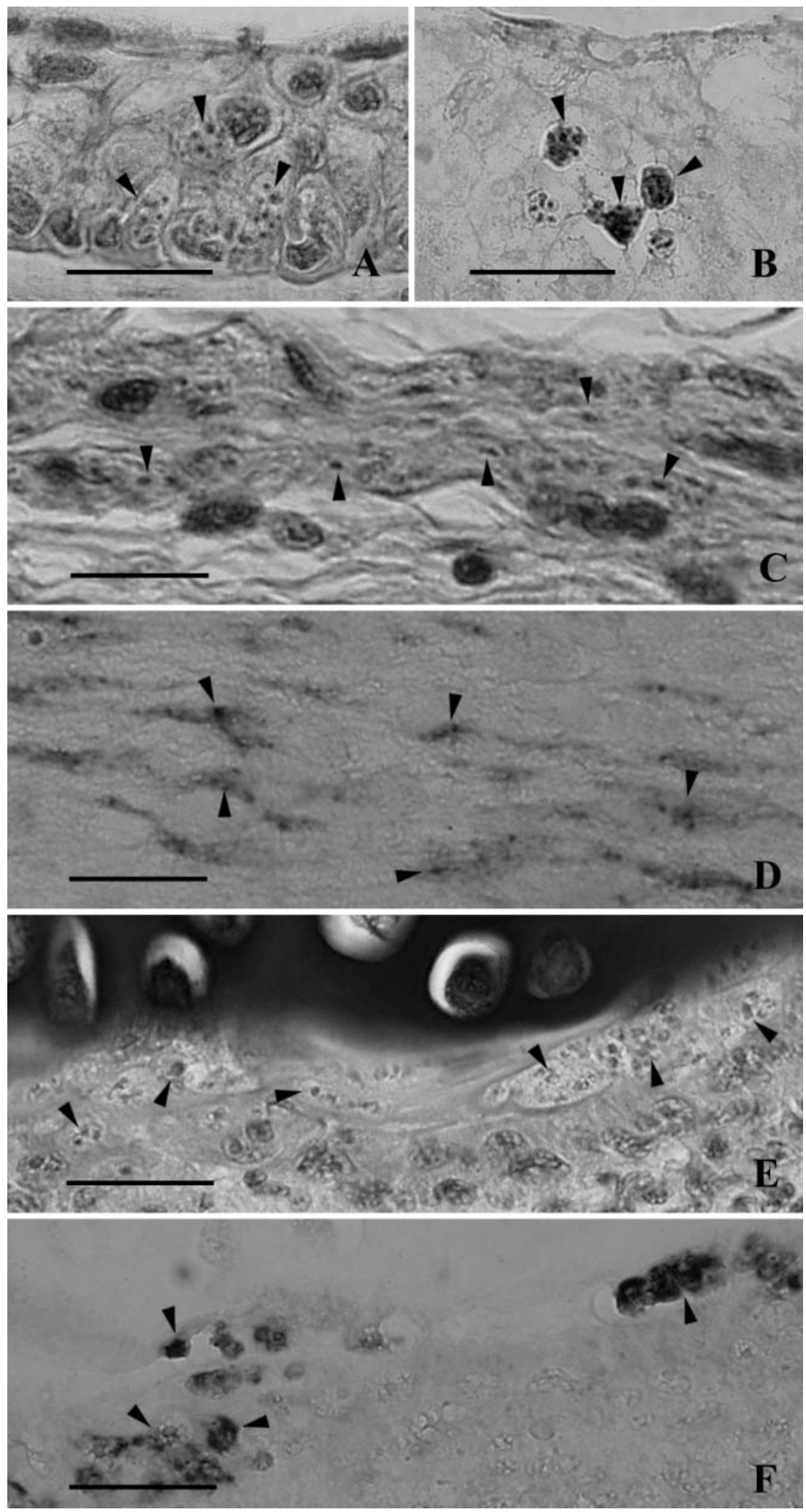

Fig. 4. Myxobolus cerebralis infecting Oncorhynchus mykiss. Detection of MyxSP-1 transcription from presporogonic stages of $M$. cerebralis in experimentally infected rainbow trout tissue-sections. At $2 \mathrm{~h}$ post-exposure: (A) hematoxylin and eosin (H\&E) stain shows presporogonic stages that have infected caudal fin epithelial cells and (B) similar stages expressing MyxSP-1 found by mRNA in situ hybridization. At 4 d post-exposure: (C) H\&E shows spindle-shaped and elongated development stages located in the central nervous system and (D) MyxSP-1 transcription. At $10 \mathrm{~d}$ post-exposure: (E) H\&E aggregates of presporogonic stages near cartilage of the head and (F) indicates MyxSP-1 transcription. Arrowheads indicate presporogonic stages. Scale bars $=25 \mu \mathrm{m}$ $(\mathrm{A}, \mathrm{B}), 12.5 \mu \mathrm{m}(\mathrm{C}, \mathrm{D}), 25 \mu \mathrm{m}(\mathrm{E}, \mathrm{F})$ 

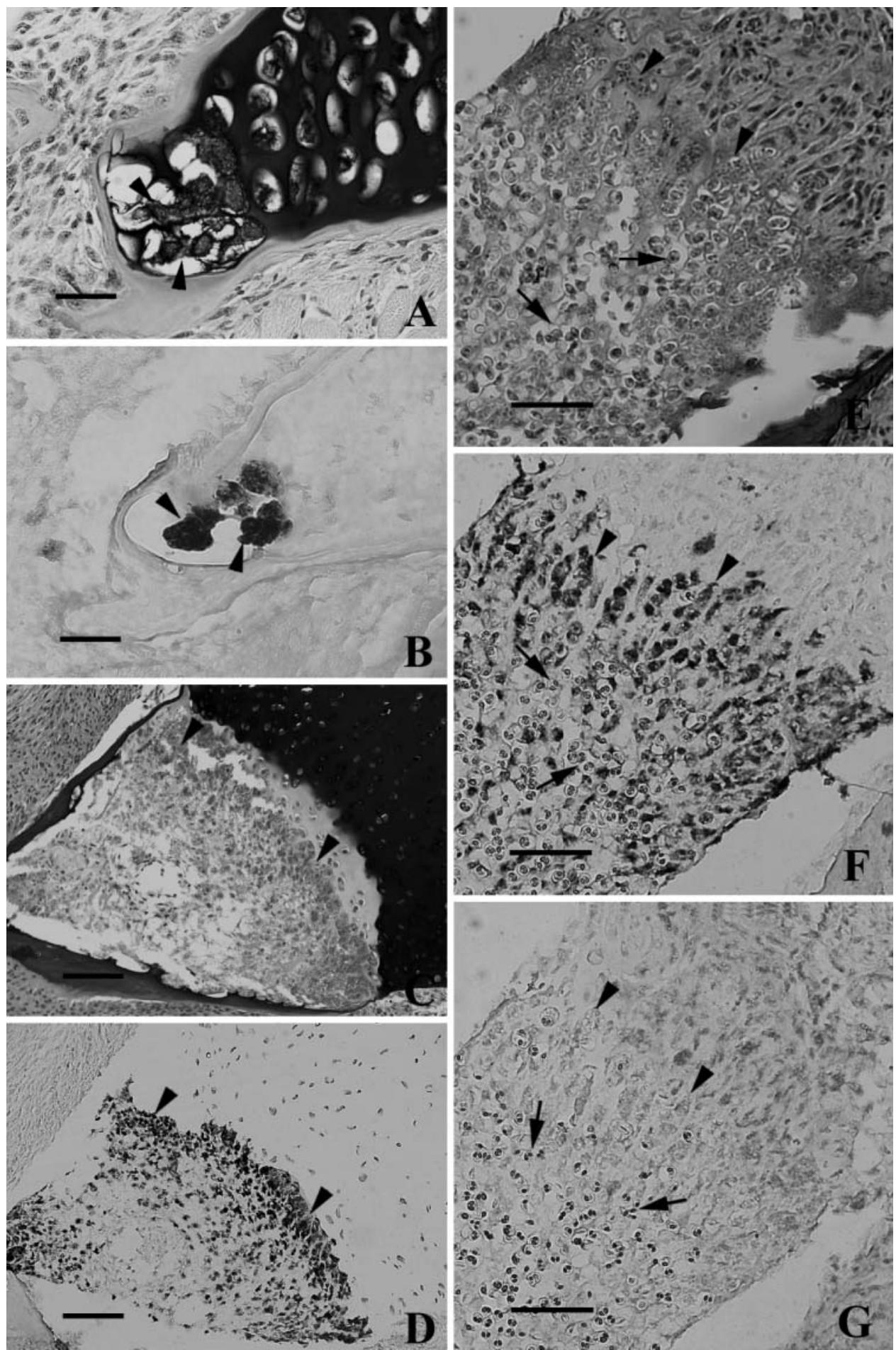

Fig. 5. Myxobolus cerebralis infecting Oncorhynchus mykiss. Detection of MyxSP-1 in experimentally infected rainbow trout tissue-sections with presporogonic and sporogonic stages of $M$. cerebralis. At $24 \mathrm{~d}$ post-exposure: (A) hematoxylin and eosin (H\&E) stain shows focal areas of presporogonic stages infecting cranial cartilage and (B) MyxSP-1 transcription. At 54 d post-exposure: (C) H\&E stain shows tissue sections of cartilage in the head with numerous parasites, and (D) expression of MyxSP-1 in association with zones of chondrocyte lysis and degeneration. At $240 \mathrm{~d}$ post-exposure: (E) H\&E stain shows tissue section of cartilage near the ventral calvarium infected with sporogonic stages, and (F) presporogonic stages expressing MyxSP-1. (G) mRNA in situ control test indicating no hybridization signal when infected tissues were probed with MyxSP-1 sense probes. Arrowheads indicate presporogonic stages and arrows show sporogonic (also referred to as myxospores) stages. Scale bars $=25 \mu \mathrm{m}(\mathrm{A}, \mathrm{B}), 100 \mu \mathrm{m}$ 
transcription associated with developmental stages found in epithelial and nerve tissues, and in conjunction with lesions in the cartilage of experimentally infected rainbow trout.

Although no significant protease sequence identities were found outside the catalytic sites, the MyxSP-1 protein sequence did contain the conserved catalytic triad and surrounding amino acid residues that are characteristic for serine proteases (present Fig. 2, and Rawlings \& Barrett 1994, Barrett \& Rawlings 1995). In addition, Rawlings \& Barrett (1994) reported that a key aspect of the evolutionary division of serine proteases is based on the linear sequence arrangement of the catalytic residues. The linear sequence data for the catalytic triad of MyxSP-1 (His-54, Asp-248, Ser-310) indicates an evolutionary affinity with chymotrypsin-like serine proteases. Unexpectedly, we found that the 3' UTR of MyxSP-1 contains a $366 \mathrm{bp}$ region that significantly complemented that found with the 18S rDNA and ITS-1 genes for Myxobolus cerebralis. The insertion of eukaryotic $18 \mathrm{~S}$ rDNA sequence within serine protease genes has been previously reported for Schistosoma mansoni (Newport et al. 1988), but the significance and function of the rDNA insertion is not known. Similarly, the function of the rDNA sequence found in the MyxSP-1 gene remains unclear, but the location of the sequence after the stop codon and in the 3' UTR suggests that the 18S rDNA and ITS-1 inserts are pseudogenes. Future studies will be needed to examine how specific sequence characteristics for MyxSP-1 play a role in protein structure, function, and substrate specificities.

Prior studies (Andree et al. 1998, Antonio et al. 1998, Baldwin \& Myklebust 2002, Schisler et al. 2001) have reported effective molecular methods for detecting Myxobolus cerebralis, but these tests provided no biological explanation for parasite activity during disease development. Using MyxSP-1 as the target gene, our real-time TaqMan PCR test detected protease transcription from early, intermediate, and late developmental stages of the parasite (Fig. 3). The spatial and temporal appearance of parasite stages in our study were consistent with an in-depth light and electron microscopic study of the sequential development of $M$. cerebralis in rainbow trout tissues by El-Matbouli et al. (1995) and trials detecting presporogonic and sporogonic stages using newly developed molecular-based assays (Andree et al. 1998, Antonio et al. 1998, 1999). From 5 min to $10 \mathrm{~d}$ post exposure, the mean values for MyxSP-1 transcription in the gills were greater than those found in any other location susceptible to parasite invasion. The respiratory epithelium is a common site for host-tissue invasion and trapping of triactinomyxons by gill filaments or gill rakers may have increased the number of parasites infecting the gill tis- sues during exposure. The consistently high level of protease transcription found in gill tissues up to $24 \mathrm{~d}$ post exposure was probably a function of a heavy exposure and numerous parasites residing in the nerve and cartilage tissues of the gills before the onset of sporogenesis. We found a significant increase in protease transcription at $2 \mathrm{~h}$ post exposure from the gill and dorsal fin compared to other host tissues at this time point (Fig. 3). The high level of MyxSP-1 expression in the gill and dorsal fin may reflect a role of this enzyme in allowing presporogonic cell-doublet stages to penetrate additional epithelial cells or for the intercellular parasite stages to migrate deeper into host tissues of the subcutis to reach peripheral nerves (ElMatbouli et al. 1995). From 2 h to 240 d post exposure, the decreasing trend for $M y x$ SP-1 transcription found in the caudal and dorsal fins, gills, and muscle tissues suggests that presporogonic stages once present in epithelial tissues advanced on to the nerves and cartilage, as found in the spine and head of the fish (Fig. 3). El-Matbouli et al. (1995) demonstrated that between 4 and $24 \mathrm{~d}$ post exposure the presporogonic stages are less frequently observed in epithelial tissues and are more abundant in peripheral, and then central nerves, and eventually the cartilage. The significant decrease in protease transcription at $10 \mathrm{~d}$ post exposure may suggest that MyxSP-1 plays a minor role during presporogonic replication in the CNS.

However, other significant changes in the temporal (4 to 24 d) transcription of MyxSP-1 in the spine and head (regions of greater nerve and cartilage concentrations) may be a function of enzymatic activities involved with penetration of nervous tissues, interaxonal migration, egress and the lysis of cartilage. Presporogonic stages found in the central nervous system beginning at $4 \mathrm{~d}$ post exposure possess distinct pseudopodia-like cytoplasmic protrusions (El-Matbouli et al. 1995). These pseudopodia-like protrusions combined with significant levels of MyxSP-1 transcription may allow presporogonic stages to migrate through host tissues and later intracellular digestion of proteins from lysed host cells. The formation of mature spores (myxospores) in fish tissues may require between 52 and $90 \mathrm{~d}$ at water temperatures of $15^{\circ} \mathrm{C}$ (Halliday 1973). Under our test conditions, sporogenesis was in the late stages by $240 \mathrm{~d}$ post exposure and this was consistent with greater $M y x$ SP-1 transcription from the spine and head, and less or none in other tissues examined (Fig. 3). Additional studies that examine protease transcription from more lightly infected fish and from different fish species are warranted. These investigations could quantify the presences of MyxSP-1 in relation to differences in the pathogenesis of disease in resistant compared to susceptible fish hosts. 
The mRNA ISH protocol reported here detected MyxSP-1 transcription from all presporogonic stages observed in fixed tissues of Myxobolus cerebralisinfected trout. Previous ISH studies have examined the utility of different fixatives for detecting parasitic rDNA in infected fish tissues (Antonio et al. 1998, 1999, Frasca et al. 1999, Morris et al. 1999, Sanchez et al. 1999, Jones et al. 2003). Our mRNA ISH test showed that fish tissues fixed for $48 \mathrm{~h}$ with Davidson's solution sufficiently inactivated RNases without damaging tissue morphology or probe hybridization. The digoxigenin labeling of $M y x S P-1$ probes and a previously described immunohistochemical detection protocol (Antonio et al. 1998) provided a sensitive nonradioactive method for identifying parasitic protease transcription in moderately to heavily infected rainbow trout. Visually detecting MyxSP-1 transcription within infected fish tissues supports our real-time PCR data and, more importantly, supports the spatial distribution of developmental stages as previously described by El-Matbouli et al. (1995) and Antonio et al. (1998, 1999). Although the rDNA ISH assay described by Antonio et al. (1998, 1999) accurately detected developmental stages from infected rainbow trout tissues, it provided no explanation for presporogonic biological activity along with lesion formation. We observed strong MyxSP-1 hybridization signals from early developmental stages of the parasite $(5 \mathrm{~min}$ to $2 \mathrm{~h}$ post exposure) in epithelial tissues. The expression of MyxSP-1 during initial host epithelial cell invasion strongly implicates this enzyme as a possible catalytic mechanism used to break down extracellular matrix proteins that would allow sporoplasm aggregates and free sporoplasm cells of $M$. cerebralis to migrate between or invade host epithelial cells. A significant advantage of the mRNA ISH test was the straightforward recognition (Fig. 4D,F) of developmental stages from 4 to $10 \mathrm{~d}$ post exposure that might otherwise be difficult to identify by rDNA ISH or light microscopy using traditional tissue stains. MyxSP-1 transcription detected presporogonic stages at 4 to $10 \mathrm{~d}$ post exposure that were accompanied by host cellular injury or reaction in peripheral nerves or the CNS. As in the epidermis and subcutis, the expression of $M y x$ SP-1 may facilitate migration through nerve cells. At 54 and 240 d post exposure, when most parasite stages have reached the cartilage, MyxSP-1 transcription was associated with presporogonic stages involved in the induction of severe host-tissue degeneration (Fig. 5D,F). At these later time points, lesions in host tissues were characterized by severe cartilage degradation and necrosis (Fig. 5C,E). The detection of protease transcription by ISH in the cartilage and associated with cartilage destruction was consistent with our real-time TaqMan PCR findings that demon- strated high levels of $M y x S P-1$ transcription during lesion development.

Our studies describe the first serine protease gene (MyxSP-1) from a member of the phylum Myxozoa, and in particular from the salmonid parasite Мyхоbolus cerebralis. The conserved catalytic triad of MyxSP-1 is linearly arranged, suggesting functions similar to that of chymotrypsin-like serine proteases. The chymotrypsin-like serine proteases secreted by the human pathogen Schistosoma mansoni are responsible for parasite penetration of skin and passage through the extracellular matrix of host tissues (Keene et al. 1983, McKerrow et al. 1983, 1985, Newport et al. 1988, Salter et al. 2000). We suspect that MyxSP-1 serves a similar role for $M$. cerebralis in the fish host. Both real-time TaqMan PCR and mRNA ISH provided evidence linking in vivo expression of the MyxSP-1 gene with key features of the pathogenesis of whirling disease.

Additional studies that further link protease expression with key pathological features of whirling disease are needed. These include examining dose responses, substrate-specificities and protease inhibitors on activity of MyxSP-1. Also, studies that demonstrate that parentally delivered anti- MyxSP-1 antibodies prepared to recombinant or synthetically made protein that alter the pathogenesis of the disease in rainbow trout are warranted. Lastly, exploitation of unique amino acid motifs of MyxSP-1 as targets for chemotherapeutics or anti-parasite vaccine development should be pursued.

Acknowledgements. This work was supported by the US Fish and Wildlife Service, and the Whirling DiseaseFoundation. We would also like to thank K. Andree and K. Beauchamp for help with molecular methods and analyses. We also are grateful to T. McDowell and K. Mukkatira for collecting parasite spores and maintaining oligochaete cultures. We appreciate the assistance of Robert Kim, Josephine Lee, and Jeannine Berger Pusterla for collection of data, and the Lucy Whittier Molecular and Diagnostic Core Facility for technical support.

\section{LITERATURE CITED}

Altschul SF, Gish W, Miller W, Myers EW, Lipman DG (1990) Basic local alignment search tool. J Mol Biol 215:403-410 Andree KB, MacConnell E, Hedrick RP (1998) A nested polymerase chain reaction for the detection of genomic DNA of Myxobolus cerebralis in rainbow trout Oncorhynchus mykiss. Dis Aquat Org 34:145-154

Andree KB, El-Matbouli M, Hedrick RP (1999) Comparison of $18 \mathrm{~S}$ and ITS-1 rDNA sequences of specific geographic isolates of Myxobolus cerebralis. Int J Parasitol 29:771-775

Antonio DB, Andree KB, McDowell TS, Hedrick RP (1998) Detection of Myxobolus cerebralis in rainbow trout (Oncorhynchus mykiss) and oligochaete tissues using a nonradioactive in situ hybridization protocol. J Aquat Anim Health 10:338-347

Antonio DB, El-Matbouli M, Hedrick RP (1999) Detection of 
early developmental stages of Myxobolus cerebralis in fish and tubificid oligochaete hosts by in situ hybridization. Parasitol Res 85:942-944

Baldwin TJ, Myklebust KA (2002) Validation of a single round polymerase chain reaction assay for identification of Myxobolus cerebralis myxospores. Dis Aquat Org 49: 185-190

Baldwin TJ, Vincent ER, Silflow RM, Stanek D (2000) Myxobolus cerebralis infection in rainbow trout (Oncorhynchus mykiss) and brown trout (Salmo trutta) exposed under natural stream conditions. J Vet Diagn Investig 12: 312-321

Barrett AJ, Rawlings ND (1995) Families and clans of serine peptidases. Arch Biochem Biophys 318:247-250.

Beauchamp KA, Gay M, Kelley GO, El-Matbouli M, Kathman RD, Nehring RB, Hedrick RP (2002) Prevalence and susceptibility of infection to Myxobolus cerebralis, and genetic differences among populations of Tubifex tubifex. Dis Aquat Org 51:113-121

Bilinski E, Boyce NP, Jonas REE, Peters MD (1984) Characterization of protease from the myxosporean salmon parasite, Henneguya salminicola. Can J Fish Aquat Sci 41:371-376

El-Matbouli M, Hoffmann RW (1991) Prevention of experimentally induced whirling disease in rainbow trout Oncoryhnchus mykiss by Fumagillin. Dis Aquat Org 10: 109-113

El-Matbouli M, Hoffmann RW (1998) Light and electron microscopic study on the chronological development of Myxobolus cerebralis in Tubifex tubifex to the actinosporean stage triactinomyxon. Int $\mathrm{J}$ Parasitol 28: 195-217

El-Matbouli M, Hoffmann RW, Mandok C (1995) Light and electron microscopic observations on the route of the triactinomyxon-sporoplasm of Myxobolus cerebralis from epidermis into rainbow trout cartilage. J Fish Biol 46: 919-935

Frasca S Jr, Linfert DR, Tsongalis GJ, Gorton TS, Garmendia AE, Hedrick RP, West AB, van Kruiningen HJ (1999) Molecular characterization of the myxosporean associated with parasitic encephalitis of farmed Atlantic salmon Salmo salar in Ireland. Dis Aquat Org 35:221-233

Halliday MM (1973) Studies on Myxosoma cerebralis, a parasite of salmonids II. The development and pathology of Myxosoma cerebralis in experimentally infected rainbow trout (Salmo gairdneri) fry reared at different temperatures. Nord Vetmed 25:349-358

Halliday MM (1976) The biology of Myxosoma cerebralis, the causative agent of whirling disease of salmonids. J Fish Biol 9:339-357

Hartley BS (1964) Amino-acid sequence of bovine chymotrypsinogen-A. Nature 201:1284-1287

Hedrick RP, El-Matbouli M, Adkison M, MacConnell E (1998) Whirling disease: re-emergence among wild trout. Immunol Rev 166:365-376

Hedrick RP, McDowell TS, Gay M, Marty GD, Georgiadis MP, MacConnell E (1999a) Comparative susceptibility of rainbow trout Oncorhynchus mykiss and brown trout Salmo trutta to Myxobolus cerebralis, the cause of salmonid whirling disease. Dis Aquat Org 37:173-183

Hedrick RP, McDowell TS, Mukkatira K, Georgiadis MP, MacConnell E (1999b) Susceptibility of selected inland salmonids to experimentally induced infections with Myxobolus cerebralis the causative agent of whirling disease. J Aquat Anim Health 11:330-339

Hedrick RP, McDowell TS, Mukkatira K, Georgiadis MP, MacConnell E (2001) Susceptibility of three species of anadromous salmonids to experimentally induced infec- tions with Myxobolus cerebralis, the causative agent of whirling disease. J Aquat Anim Health 13:43-50

Jones SR, Goh B, Prosperi-Porta G (2003) Duration and method of fixation affects the sensitivity of digoxygeninlabelled DNA probe in detecting Kudoa thyrisites in Atlantic salmon skeletal muscle. Aquaculture 220: 157-164

Keene WE, Jeong KH, McKerrow JH, Werb Z (1983) Degradation of extracellular matrix of larvae of Schistosoma mansoni. II. Degradation by newly transformed and developing schistosomula. Lab Investig 49:201-207

Kelley GO, Francisco JZ, Leutenegger CM, Myklebust KA and 7 others (2004) Evaluation of five diagnostic methods for the detection and quantification of Myxobolus cerebralis. J Vet Diagn Investig 16:195-204

Kozak M (1981) Possible role of flanking nucleotides in recognition of the AUG initiator codon by eukaryotic ribosomes. Nucleic Acids Res 9:5233-5252

Kozak M (1999) Initiation of translation in prokaryotes and eukaryotes. Gene 234:187-208

MacConnell E, Vincent ER (2002) The effects of Myxobolus cerebralis on the salmonid host. Am Fish Soc Symp 29: 95-107

Markiw ME (1989) Salmonid whirling disease: myxosporean and actinosporean stages cross-react in a direct fluorescent antibody test. J Fish Dis 12:137-141

Markiw ME (1991) Whirling disease: earliest susceptible age of rainbow trout to the triactinomyxid of Myxobolus cerebralis. Aquaculture 92:1-6

Markiw ME (1992) Experimentally induced whirling disease. I. Dose response of fry and adults of rainbow trout exposed to the triactinomyxon stage of Myxobolus cerebralis. J Aquat Anim Health 4:40-43

Markiw ME, Wolf K (1974) Myxosoma cerebralis: isolation and concentration from fish skeletal elements - sequential enzymatic digestions and purification by differential centrifugation. J Fish Res Board Can 32:15-20

Martone CB, Spivak E, Busconi L, Folco EJ, Sánchez JJ (1999) A cysteine protease from myxosporean degrades host myofibrils in vitro. Comp Biochem Physiol B 123:267-272

McKerrow JH (1989) Parasite proteases. Exp Parasitol 68: 111-115

McKerrow JH (1999) Development of cysteine protease inhibitors as chemotherapy for parasitic diseases: insight on safety, target validation, and mechanism of action. Int J Parasitol 29:833-837

McKerrow JH, Keene WE, Jeong KH, Werb Z (1983) Degradation of extracellular matrix of larvae of Schistosoma mansoni. I. Degradation by cercariae as a model for initial parasite invasion of host. Lab Investig 49:195-200

McKerrow JH, Pino-Heiss S, Lindquist R, Werb Z (1985) Purification and characterization of an elastinolytic proteinase secreted by cercariae of Schistosoma mansoni. J Biol Chem 260:3703-3707

McKerrow JH, Sun E, Rosenthal PJ, Bouvier J (1993) The proteases and pathogenicity of parasitic protozoa. Annu Rev Microbiol 47:821-853

McKerrow JH, Engel JC, Caffrey CR (1999) Cysteine protease inhibitors as chemotherapy for parasitic infections. Bioorg Med Chem 7:639-644

Morris DJ, Adams A, Richards RH (1999) In situ hybridization of DNA probes to PKX, the causative organism of proliferative kidney disease (PKD). J Fish Dis 22:161-163

Nehring RB, Walker PG (1996) Whirling disease in the wild: the new reality in the intermountain west. Fisheries 21: $28-32$

Newport GR, McKerrow JH, Hedstrom R, Petitt M, McGar- 
rigle L, Barr PJ, Agabian N (1988) Cloning of the proteinase that facilitates infection by schistosome parasites. J Biol Chem 263:13179-13184

O'Grodnick JJ (1975) Whirling disease Myxosoma cerebralis spore concentration using the continuous plankton centrifuge. J Wildl Dis 11:54-57

O'Grodnick JJ (1979) Susceptibility of various salmonids to whirling disease (Myxobolus cerebralis). Trans Am Fish Soc 108:187-190

Que X, Kim SH, Sajid M, Eckmann L, Dinarello CA, McKerrow $\mathrm{JH}$, Reed SL (2003) A surface amebic cysteine proteinase inactivates interleukin-18. Infect Immun 71:1274-1280

Rawlings ND, Barrett AJ (1994) Families of serine peptidases. Methods Enzymol 244:19-61

Rosenthal PJ, McKerrow JH, Aikawa M, Nagasawa H, Leech $\mathrm{JH}$ (1988) A malarial cysteine proteinase is necessary for hemoglobin degradation by Plasmodium falciparum. J Clin Investig 82:1560-1566

Sakanari JA, Staunton CE, Eakin AE, Craik CS, McKerrow JH (1989) Serine protease from nematode and protozoan parasites: isolation of sequence homologs using generic molecular probes. Proc Natl Acad Sci USA 86:4863-4867

Salter JP, Lim KC, Hansell E, Hsieh I, McKerrow JH (2000)

Editorial responsibility: Wolfgang Körting,

Hannover, Germany
Schistosome invasion of human skin and degradation of dermal elastin are mediated by a single serine protease. J Biol Chem 275:38667-38673

Sambrook J, Fritsch EF, Maniatis T (1989) Molecular cloning. A laboratory manual, 2nd edn. Cold Spring Harbor Laboratory Press, Cold Spring Harbor, NY

Sanchez JG, Speare DJ, Markham RJF (1999) Nonisotopic detection of Loma salmonae (Microspora) in rainbow trout (Oncorhynchus mykiss) gills by in situ hybridization. Vet Pathol 36:610-612

Schisler GJ, Bergersen EP, Walker PG (2001) Comparison of single-round polymerase chain reaction (PCR) methods for detection of Myxobolus cerebralis. Dis Aquat Org 45:109-114

Vincent ER (1996) Whirling disease and wild trout: the Montana experience. Fisheries 21:32-34

Vincent ER (2002) Relative susceptibility of various salmonids to whirling disease with emphasis on rainbow and cutthroat trout. Am Fish Soc Symp 29:109-115

Wagner EJ (2002) Whirling disease prevention, control, and management: a review. Am Fish Soc Symp 29:217-225

Wolf K, Markiw ME (1984) Biology contravenes taxonomy in the Myxozoa: new discoveries show alternation of invertebrate and vertebrate hosts. Science 225:1449-1452

Submitted: September 1, 2003; Accepted: December 18, 2003 Proofs received from author(s): May 12, 2004 